\title{
Grafted semiconductors on PE-films leading to bacterial inactivation: synthesis, characterization and mechanism
}

\author{
A. Camarasa Mena ${ }^{a}$, S. Rtimi ${ }^{a *}$, C. Pulgarin ${ }^{a}$, J-C Lavanchy ${ }^{b}$, J. \\ Kiwi $^{\mathrm{a}}$
}

${ }^{a}$ Ecole Polytechnique Fédérale de Lausanne, EPFL-SB-ISIC-GPAO, Station 6, $\mathrm{CH}-1015$, Lausanne, Switzerland

${ }^{b}$ Lausanne University, IMG, Mineral analysis center, Bat Anthropole, CH-1015 Lausanne, Switzerland

Corresponding author: S. Rtimi, sami.rtimi@epfl.ch , Tel: +41216936150.

\section{ABSTRACT}

This study reports the colloidal preparation $\mathrm{FeOx}, \mathrm{TiO}_{2}$ and $\mathrm{FeOx}-\mathrm{TiO}_{2}$ grafted on polyethylene (PE) films leading to bacterial inactivation. A fast bacterial inactivation was attained by the $\mathrm{FeOx}-\mathrm{TiO}_{2}$ compared to the $\mathrm{FeOx}-\mathrm{PE}$ film due to the interfacial charge transfer (IFCT) $\mathrm{FeOx}$ to the lower-lying $\mathrm{TiO}_{2}$ trapped states. $\mathrm{A} \mathrm{pH}$-decrease was observed during bacterial inactivation due to the formation of carboxylic acids on the grafted films and the recovery to the initial $\mathrm{pH} \sim 7$ after elimination of the intermediates was followed quantitatively during bacterial inactivation. The potential on the $\mathrm{TiO}_{2}-\mathrm{PE}, \mathrm{FeOx}-\mathrm{PE}$ and $\mathrm{FeOx}-\mathrm{TiO}_{2}-\mathrm{PE}$ film surfaces decreased during the bacterial inactivation concomitant with the loss of the cell wall permeability. Different mechanisms for the photo-induced E. coli inactivation for random nanoparticulate $\mathrm{FeOx}-\mathrm{PE}$ and $\mathrm{FeOx}-\mathrm{TiO}_{2}-\mathrm{PE}$ films are suggested based on the experimental observations reported in this study. During the inactivation of $E$. coli, the Fe-ions were seen to leach out in amounts $\leq 0.45$ $\mathrm{ppm}$. This is within the EU sanitary allowed limits for industrial/drinking water. The wettability of the films was followed by contact angle measurements (CA) within the time of bacterial inactivation. By diffuse reflectance spectroscopy (DRS), the conversion of the $\mathrm{Fe}$ (III)-oxide to $\mathrm{Fe}(\mathrm{II})$-oxide is reported during film recycling. The change in the Fe-oxidation states within the bacterial inactivation was further confirmed by X-ray photoelectron spectroscopy (XPS).

Keywords: semiconductor films, colloidal preparations, grafting of nanoparticles, bacterial inactivation, IFCT. 


\section{INTRODUCTION}

Bacterial inactivation materials/films have widely used $\mathrm{TiO}_{2}$ and Fe-oxides under sunlight irradiation leading to highly oxidative radicals [1-7]. $\mathrm{TiO}_{2}$ absorbs only $4-5 \%$ of the incident solar radiation with an absorption edge at $\sim 390 \mathrm{~nm}$. A method to increase the visible light absorption is to couple $\mathrm{TiO}_{2}$ with narrow band-gap iron-oxide(s) semiconductor [8-9]. Fe-oxides have also been used as $\mathrm{TiO}_{2}$ dopants due to its small band gap $(\sim 2.2 \mathrm{eV})$ for $\alpha-\mathrm{Fe}_{2} \mathrm{O}_{3}$, low cost and nontoxicity [10-11].

Studies with $\mathrm{FeOx}$ and the $\mathrm{FeOx}-\mathrm{TiO}_{2}$ binary oxide have shown to induce an accelerated degradation of arsenite [12], phenol [13], 4-chlorophenol [14] and humic acids [15] under visible light. More recently, our laboratory has reported $\mathrm{FeOx}-\mathrm{PE}[16]$ and $\mathrm{FeOx}-\mathrm{TiO}_{2}-\mathrm{PE}$ films [17] prepared by direct magnetron current sputtering presenting antibacterial properties. In this study we address the colloidal preparation of $\mathrm{TiO}_{2}-\mathrm{PE}, \mathrm{FeOx}-\mathrm{PE}$ and $\mathrm{FeOx}-\mathrm{TiO}_{2}$ films prepared by a simple, low temperature approach and their subsequent grafting on PE. Iron oxide nanoparticles (NP's) are of considerable interest due to their wide applications in fields such as magnetic storage, medicine, chemical industries, catalytic materials and water purification. Synthesis of $\mathrm{Fe}_{2} \mathrm{O}_{3} / \mathrm{FeO}$ have been carried out by precipitation, sol-gel, hydrothermal, dry vapor deposition, surfactant mediation, micro-emulsion, electro-deposition and sonochemical methods $[9,18-19]$. We have selected polyethylene (PE) as the substrate for the selected oxides for its stability, lack of oxidation when exposed to air and/or sunlight and its low cost. Immobilized Fe-catalysts avoid the problem of separation and filtration of the iron oxides when suspensions are used at the end of the pollutant abatement process. For this reason our laboratory has reported the degradation of pollutants on Fe-supported on PE-maleic anhydride films [20] and also on Fe immobilized on sulfonic Nafion exchange membranes [21]. The bacterial inactivation kinetics on colloidal $\mathrm{FeOx}-\mathrm{TiO}_{2}-\mathrm{PE}$ with respect to $\mathrm{FeOx}-\mathrm{PE}$ and $\mathrm{TiO}_{2}-\mathrm{PE}$ is investigated in this study addressing film surface properties.

The novelty of this study consists in the presentation: a) of an innovative colloidal preparation of oxides and their deposition on non-thermal resistant films like PE. The deposition of oxides on thermally resistant surfaces reported until 
now required temperatures of few hundred degrees necessary to anneal the oxides on the support $[10,18]$. A procedure is also presented to graft the selected oxides on PE at temperatures within the thermal resistance of $\left.\mathrm{PE}\left(<96^{\circ} \mathrm{C}\right), \mathrm{b}\right)$ the evaluation of the $E$. coli inactivation kinetics on the $\mathrm{FeOxTiO}_{2}$-coated films c) a mechanistic outline for the photo-induced charge from $\mathrm{FeOx}$ to $\mathrm{TiO}_{2}$, based on $\mathrm{X}$ ray photo-electron spectroscopy (XPS) providing a proof for the redox process taking place during bacterial inactivation and d) the film properties characterized by several complementary techniques such as: $\mathrm{X}$-ray fluorescence (XRF), diffuse reflection spectroscopy (DRS), contact angle (CA), surface potential changes and $\mathrm{X}$-ray photoelectron spectroscopy (XPS).

\section{Experimental}

2.1 Preparation of $\mathrm{TiO}_{2}, \mathrm{FeOx}$ and $\mathrm{FeOx}-\mathrm{TiO}_{2}$ colloids and $\mathrm{PE}$ functionalization and determination of the oxide loading on PE by XRF

Colloidal solutions of $\mathrm{FeCl}_{3}$ and $\mathrm{TiO}_{2}$ Degussa P25 were prepared using the concentration of $\mathrm{FeCl}_{3}(100 \mathrm{mg} / \mathrm{L})$ and $\mathrm{TiO}_{2}(5 \mathrm{~g} / \mathrm{L})$ to photo-corrode the PE. The photo-corrosion was carried out under UV irradiation for $15 \mathrm{~h}$. For this purpose BLB lamp Philips TLD-15W/08 SLV was used providing monochromatic $366 \mathrm{~nm}$ light with an integral output of $4.3 \mathrm{~mW} / \mathrm{cm}^{2}$. The photo-corrosion step introduces oxidative chelating sites to bind the oxides $\left(\mathrm{TiO}_{2}\right.$ and/or $\left.\mathrm{FeOx}\right)$. After the UVirradiation, the films were sonicated in aqueous solution for $10 \mathrm{~min}$ to remove loose bound oxide particles, washed and dried and dried for $10 \mathrm{~min}$ at $80^{\circ} \mathrm{C}$. Afterwards, the PE was functionalized in air by contacting different concentrations of $\mathrm{FeOx}$ and/or $\mathrm{TiO}_{2}$ for 2 hours. This deposition was made without further UV-photo-assisted illumination. This operation was repeated twice and the loaded films were dried at $60^{\circ} \mathrm{C}$.

The amounts of $\mathrm{Fe}$ and $\mathrm{Ti}$ on PE were determined by X-ray fluorescence spectroscopy (XRF) in a PANalytical PW2400 spectrometer and are shown in Table 1.

The polyethylene (PE) film used consisted of highly branched low crystalline semi-transparent film with the formula $\mathrm{H}\left(\mathrm{CH}_{2}-\mathrm{CH}_{2}\right) \mathrm{H}$. The (LDPE) $0.1 \mathrm{~mm}$ thick was obtained from Goodfellow (UK, ET3112019) had a density of $0.92 \mathrm{~g} / \mathrm{cm}^{3}$. 
2.2 E. coli inactivation on $\mathrm{FeOx}-\mathrm{TiO}_{2}-\mathrm{PE}$ films, irradiation procedures and determination of the Fe leached out from the films during bacterial inactivation

The samples of Escherichia coli (E. coli K12) on $2 \mathrm{~cm}$ by $2 \mathrm{~cm}$ FeOx-PE, $\mathrm{TiO}_{2}-\mathrm{PE}$ and $\mathrm{FeOx}-\mathrm{TiO}_{2}-\mathrm{PE}$ were placed into a glass Petri dish and irradiated in the cavity of Sunlight simulated cavity set at one half of the maximum sunlight intensity $\left(50 \mathrm{~mW} / \mathrm{cm}^{2}\right)$ emitting in the range $310-800 \mathrm{~nm}$. The $100 \mu \mathrm{L}$ culture aliquots with an initial concentration of $\sim 10^{6}$ colony forming units (CFU mL ${ }^{-1}$ ) in $\mathrm{NaCl} / \mathrm{KCl}(\mathrm{pH} 7)$ were placed on coated PE. After preselected irradiation times, the fabric was transferred into a sterile Eppendorf tube containing $900 \mu \mathrm{L}$ autoclaved $\mathrm{NaCl} / \mathrm{KCl}$ saline solution. This solution was subsequently mixed thoroughly using a Vortex. Serial dilutions were made in $\mathrm{NaCl} / \mathrm{KCl}$ solution. Samples of $100-\mu \mathrm{L}$ were pipetted onto a nutrient agar plate and then spread over the surface of the plate using standard plate method. Agar plates were incubated lid down, at $37^{\circ} \mathrm{C}$ for $24 \mathrm{~h}$ before counting. Three independent assays were carried out for each sputtered sample. The coated and uncoated (control) films were kept in a sterile oven at $60^{\circ} \mathrm{C}$ to avoid contamination prior to the bacterial test. Films irradiation was carried out on Petri dishes provided with a lid to prevent the bacterial suspension evaporation. The agar was purchased from Merck $\mathrm{GmbH}$, Microbiology division KGaA under the catalogue $N^{\circ} 1.05463 .0500$. The CFU statistical analysis of the bacteria inactivation data was performed calculating the standard deviation values.

The irradiation of the samples was carried out in the cavity of a sunlight simulator from Atlas Material Testing Solutions (Harkingen, Switzerland) tuned at a light dose of $50 \mathrm{~mW} / \mathrm{cm}^{2}$ provided for with a filter blocking the light $<310 \mathrm{~nm}$.

Ferrozine was used to evaluate the total iron concentration leaching out during the bacterial inactivation following the optical absorption $562 \mathrm{~nm}$ of the $\mathrm{Fe}(\mathrm{II})$, in a buffered solution [24]. The Fe(III) species was determined by difference adding hydroxylamine hydrochloride to reduce the $\mathrm{Fe}(\mathrm{III})$ to $\mathrm{Fe}$ (II)-species, its absorbance peak taken after 3 min again at $562 \mathrm{~nm}$. The addition of the two Fespecies is reported in this study during the bacterial inactivation period.

2.3 Diffuse reflectance spectroscopy (DRS), contact angle (CA) and surface potential changes during bacterial inactivation on $\mathrm{TiO}_{2}, \mathrm{FeOx}$ and $\mathrm{FeOx}-\mathrm{TiO}_{2}-\mathrm{PE}$ films. 
Diffuse reflectance spectroscopy (DRS) was carried out in a Perkin Elmer Lambda 900 UV-VIS-NIR spectrometer provided for with a PELA-1000 accessory within the wavelength range of $200-800 \mathrm{~nm}$ and a resolution of $1 \mathrm{~nm}$. The absorption of the samples was plotted in Kubelka-Munk (KM/S units) vs wavelength.

The CA of the films were determined by the sessile drop method on a DataPhysics OCA 35 unit. Drop volumes of 0.5 microliter were chosen in all experiments to avoid shape alteration due to gravitational forces and to diminish the evaporation effects. The measurements were performed at room temperature (65\% controlled humidity). The drop image was registered in a CCD camera $(1280 \times 960$ pixels) attached to a microscope and processed by way of software image analysis to estimate the contact angle.

The local $\mathrm{pH}$ and surface potential changes within the bacterial inactivation were followed by the mean of a Jenco $6230 \mathrm{~N}(\mathrm{pH} / \mathrm{mV} / \mathrm{Temp}$ meter) provided for with a hand held microprocessor in splash proof case with 3 points calibration. The data was monitored via RS-232-C IBM compatible communication interface and BNC, pH/ORP connector with 8-pin DIN ATC connector.

2.4 The X-ray photoelectron spectroscopy (XPS) of the films during bacterial inactivation

The X-ray photoelectron spectroscopy (XPS) of the films was carried out using an AXIS NOVA photoelectron spectrometer (Kratos Analytical, Manchester, UK) provided for with a monochromatic AlK $_{a}(\mathrm{~h} v=1486.6 \mathrm{eV})$ anode. The carbon $\mathrm{C} 1 \mathrm{~s}$ line with position at $284.6 \mathrm{eV}$ was used as a reference to correct the charging effect. The surface atomic concentration was determined from peak areas using the known sensitivity factors for each element [25]. Spectrum background was subtracted according to Noggier et al., [26]. Deconvolution of the XPS peaks was carried out taking into consideration the Shirley background correction and Gaussian-Lorentzian peak shape with a G-L ratio of 30 . The XPS spectral peaks were deconvoluted with a CasaXPS-Vision 2, Kratos Analytical UK.

\section{Results an discussions}

3.1 Bacterial inactivation on PE-coated films and amount of Fe-eluted during the bacterial inactivation process 
Figure 1 shows the bacterial inactivation under low intensity simulated solar light on $\mathrm{FeOx}_{-} \mathrm{TiO}_{2}-\mathrm{PE}$ films within 90 minutes, on $\mathrm{FeOx}-\mathrm{PE}$ within 120 minutes and finally on $\mathrm{TiO}_{2}-\mathrm{PE}$ at $240 \mathrm{~min}$. Therefore, semiconductors with a different make up under light or their combinations led to different bacterial inactivation times. The mechanism of $\mathrm{FeOx}$ charge photo-generation will not be described in this study since it has been recently reported in our laboratory [16]. Also the $\mathrm{TiO}_{2}$ PE mediated bacterial inactivation has been reported widely in the open literature $[1-3,18]$. Below eqs (1-6) outline the photo-induced bacterial inactivation due to $\mathrm{TiO}_{2}-\mathrm{PE}$ shown in Figure 1, trace 2:

$$
\begin{array}{cc}
\text { Bacteria }+\left[\mathrm{TiO}_{2}-\mathrm{PE}\right]+\text { light } \rightarrow\left[\mathrm{TiO}_{2}{ }^{*}-\mathrm{PE}\right] & \text { Bacteria } \rightarrow\left[\text { Bacteria }^{+} \ldots \mathrm{TiO}_{2}\left(\mathrm{cbe}^{-}\right)-\mathrm{PE}\right] \\
\mathrm{TiO}_{2}(\mathrm{cbe}-)-\mathrm{PE}+\mathrm{O}_{2}+\mathrm{H}^{+} \rightarrow \mathrm{HO}_{2}{ }^{\circ} & \mathrm{E}_{0}-0.05 \mathrm{NHE} \text { [27] } \\
\mathrm{TiO}_{2}(\mathrm{cbe}-)-\mathrm{PE}+\mathrm{O}_{2 \text { ads }} \rightarrow \mathrm{O}_{2}{ }^{-} \text {ads } & \mathrm{E}_{0}-0.16 \mathrm{NHE} \quad[27] \\
\mathrm{TiO}_{2}\left(\mathrm{vbh}^{+}\right)-\mathrm{PE}+\mathrm{OH}^{-} \text {ads } \rightarrow \mathrm{OH}^{\circ} & \mathrm{E}_{0}-1.90 \mathrm{NHE} \quad[9] \\
\mathrm{TiO}_{2}\left(\mathrm{vbh}^{+}\right)-\mathrm{PE}+\mathrm{H}_{2} \mathrm{O}_{\text {ads }} \rightarrow \mathrm{OH}^{\circ} \text { ads }+\mathrm{H}^{+} & \\
\mathrm{O}_{2}{ }^{--}+\mathrm{H}^{+} \Leftrightarrow \mathrm{HO}_{2}{ }^{\circ} & \mathrm{pK}_{\mathrm{a}} 4.8
\end{array}
$$

In reaction (2), the $\mathrm{HO}_{2}{ }^{\circ}$ radical generated under light is stable at $\mathrm{pH}<4.8$, but above this $\mathrm{pH}$ more than $50 \%$ (as noted in eq.3) in the form of $\mathrm{O}_{2}{ }^{-}$as noted in reaction (6).

Figure 1, trace 3 presents the bacterial inactivation mediated by $\mathrm{FeOx}-\mathrm{TiO}_{2}-$ $\mathrm{PE}$. This later film is seen to accelerate the bacterial inactivation kinetics respect to the $\mathrm{TiO}_{2}$ and $\mathrm{FeOx}$ coated PE-films. Therefore, the interaction going on between the random coated $\mathrm{FeOx}$ and $\mathrm{TiO}_{2}$ on the PE film surface accelerates the observed bacterial inactivation. A mechanism will be suggested at a later stage in section 3.4 consistent with the observed results.

Figure 2 presents the Fe-leaching by way of ferrozine (see experimental section) during bacterial inactivation. Figure 2a shows the Fe-leaching for FeOx-PE films. In this case, the electrostatic attraction between the negative $E$. coli envelope and the positively charged FeOx (I.E.P. 9) film plays a role. This interaction occurs in the $\mathrm{pH}$ range 6-7 tolerable by the bacterial cells. For this reason, Figure $2 \mathrm{a}$, trace (2) shows a low Fe-leaching within the 120 min bacterial inactivation time. Figure $2 \mathrm{~b}$ presents the same trend for the Fe-leaching from $\mathrm{FeOx}-\mathrm{TiO}_{2}$ films within the $90 \mathrm{~min}$ 
bacterial inactivation time. In both cases, the Fe-leached is below the limit of 1-2 $\mathrm{mg} / \mathrm{L} \mathrm{Fe}$ set for drinking water [28].

\subsection{UV-Vis spectroscopic properties and surface wettability of coated-PE films}

Figure 3a shows the DRS spectra of $\mathrm{TiO}_{2}$ and $\mathrm{FeOx}$ in Kubelka-Munk units. The spectrum of FeOx shown in Figure $3 a$ suggests that the main component is hematite showing an absorption similar to the one presented in Figure 3 [29]. The absorption spectrum between 250 and $450 \mathrm{~nm}$ in Figure 2a is attributed to $\mathrm{Fe}_{2} \mathrm{O}_{3}$ and to amorphous/anatase $\mathrm{TiO}_{2}$ with bigger particle sizes. The higher amplitude of the $\mathrm{TiO}_{2}$ spectrum in Figure 3a was due to the larger $\mathrm{TiO}_{2}$ particles compared to their $\mathrm{FeOx}\left(\mathrm{Fe}_{2} \mathrm{O}_{3}\right)$ counterparts. Both spectra have been extensively reported as a function of the film thickness and particulate grain size $[9,18]$. Figure $3 b$ shows that the spectra of $\mathrm{FeOx}-\mathrm{TiO}_{2}-\mathrm{PE}$ after several bacterial inactivation cycles. The $\mathrm{FeOx}-$ $\mathrm{TiO}_{2}$-films spectral absorption presents only a minor variation providing the proof for the stability of the coating described in section 2.1. Due to the low temperature used during the film preparation, the incorporation of $\mathrm{FOx}$ in the $\mathrm{TiO}_{2}$ lattice seems not to be possible. But the random distribution of the $\mathrm{FeOx}$ and $\mathrm{TiO}_{2}$ particles in the colloidal coated film may involve charge transfer between these two particles. This will be discussed below in section 3.4 in relation to the photo-induced interfacial charge transfer (IFCT) between $\mathrm{FeOx}$ and $\mathrm{TiO}_{2}$.

The hydrophobic to hydrophilic transformation for the $\mathrm{FeOx}-\mathrm{TiO}_{2}-\mathrm{PE}$ films under low intensity sunlight is shown next in Figure 4. The hydrophobic FeOx$\mathrm{TiO}_{2}$-PE film at time zero presents and angle of $\sim 100^{\circ}$ decreasing under light within the time of bacterial inactivation to $32^{\circ}(90 \mathrm{~min}$ ) [30]. The recovery in the dark towards an increased hydrophobicity is shown in Figure $3 \mathrm{~b}$ beginning around $22^{\circ}$ and proceeding slowly in the time scale up to $3000 \mathrm{~min}$. The fact that the recovery in the dark starts at $22^{\circ}$ and not $32^{\circ}$ was due to the 6 hours elapsed when taking the last point in Figure 4, trace 1 before registering the zero point reported in Figure 4, trace 2. The $\mathrm{FeOx}-\mathrm{TiO}_{2}-\mathrm{PE}$ film increase in hydrophilicity continues after 90 min irradiation approaching the super-hydrophilicity range [31]. Recently, Amal et al., have reported reversibly photo-switching within cyclic lightdark cycles mediated by the Ag-particles [32]. The hydrophilic or hydrophobic character of the bacterial cell-wall envelope is important for the adhesion of E. coli 
an event preceding inactivation. E. coli has been shown to present preferential adhesion to hydrophilic surfaces [33].

3.3 X-ray photoelectron spectroscopy (XPS) micro-potential analysis and shift in the local $\mathrm{pH}$ during bacterial inactivation.

Figure 5a/a shows the deconvolution of the Fe- XPS peaks of the FeOx$\mathrm{TiO}_{2}-\mathrm{PE}$ film before bacterial inactivation. The $\mathrm{Fe}$-ion, $\mathrm{Fe}_{2} \mathrm{O}_{3}, \mathrm{FeOOH}$ and $\mathrm{FeOH}$ peaks have been assigned according to Wagner [25] and the data corrected for electrostatic charging according to Shirley [34]. After bacterial inactivation, new Fe-species and $\mathrm{Fe}^{2+}$-satellite peaks appear as seen in Figure $5 \mathrm{a} / \mathrm{b}$. A significant change in the binding energy if $\mathrm{FeOH}$ peak from $713.0 \mathrm{eV}$ to $714.2 \mathrm{eV}$ is seen after the bacterial inactivation. Redox catalysis associated with FeOx therefore plays a significant role during bacterial inactivation. This was also confirmed by the appearance of significantly shifted $\mathrm{Fe}^{2+-}$ satellite peaks concomitant with bacteria inactivation. The $\mathrm{Fe}_{3} \mathrm{O}_{4}$ after bacterial inactivation appears probably at the expense of a reduction of the $\mathrm{Fe}^{2+}$-species during the bacterial inactivation in Figure 5a/a.

Further evidence for redox catalysis by XPS is shown in Figure 5b/a. The Ti2p doublet peak of $\mathrm{FeOx}-\mathrm{TiO}_{2}-\mathrm{PE}$ film was found at $457.75 \mathrm{eV}$ before bacterial inactivation and is shifted to the $458.21 \mathrm{eV}$ after the bacterial inactivation.

The changes in $\mathrm{pH}$ and surface potential were followed within the time of bacterial inactivation and the results are presented in Figures $6 a$ and $b$. This allows to gain further insight into the changes on the surface of the film during bacterial inactivation. A mechanism of bacterial inactivation involves the generation of intermediate species by $\mathrm{TiO}_{2}$ and $\mathrm{FeOx}$ semiconductors under bandgap-irradiation $[18,35]$.

Figure 6a presents the surface $\mathrm{pH}$-shift at the FeOx-PE interface under low intensity solar light irradiation. A pH-decrease between 7.0 and $\mathrm{pH} 6.5$ was observed within $30 \mathrm{~min}$. The decrease in $\mathrm{pH}$-shift is equivalent to a fourfold increase in the concentrations of $\left[\mathrm{H}^{+}\right]$. The $\mathrm{pH}$ decrease is due to short chain carboxylic acids generated in solution during the bacterial inactivation. These carboxylic acids have $\mathrm{pK}_{\mathrm{a}}$ values around $\sim 3$ [5]. After $30 \mathrm{~min}$, the $\mathrm{pH}$ recovers up to $\sim 6.7$ due to the elimination of short carboxylic acids through mineralization of 
the carboxylic acids to $\mathrm{CO}_{2}$. This is the final step in the bacterial mineralization known as the typical photo-Kolbe $\mathrm{CO}_{2}$ elimination reaction [36] and is shown below in eq(7)

$$
\mathrm{RCOO}-+\mathrm{FeOx}-\mathrm{TiO}_{2}-\mathrm{PE}+\mathrm{h} v \rightarrow \mathrm{R}^{\circ}+\mathrm{CO}_{2}
$$

Figures $6 \mathrm{~b}$ and $6 \mathrm{c}$ follow the same trend for $\mathrm{TiO}_{2}-\mathrm{PE}$ and for the $\mathrm{FeOx}-\mathrm{TiO}_{2}-\mathrm{PE}$ films respectively. A steeper $\mathrm{pH}$ decrease for the $\mathrm{pH}$-values was observed within the bacterial inactivation followed by a recover to $\mathrm{pH} 6.8$.

Figure $6 \mathrm{a}$ shows that the interface potential decrease for FeOx-PE decreases from 70 to $30 \mathrm{mV}$ during the first $5 \mathrm{~min}$ during the bacterial inactivation. This decrease in voltage at the film-surface is concomitant to the cell wall permeability. The voltage decrease is due to the loss/damage of the cell wall barrier regulating the ions exchange in and out of the cell cytoplasm [37]. As a consequence the bacteria loses $\mathrm{K}, \mathrm{Na}, \mathrm{Mg}$-ions and other essential ions, diffuse faster out of the cell wall envelope [38-39]. The surface potential recovery after 30 min in Figure 6a reflects the recovery of the $\mathrm{FeOx}-\mathrm{TiO}_{2}-\mathrm{PE}$ initial potential once the film recovers its initial microstructure after bacterial inactivation. Figure $6 \mathrm{~b}$ shows a surface potential loss and recovery similar as the one reported in Figure $6 \mathrm{a}$ but for $\mathrm{TiO}_{2}-\mathrm{PE}$ films. But Figure $6 \mathrm{c}$ shows a steeper surface potential drop of $\sim 5 \mathrm{mV}$ for the $\mathrm{FeOx}-\mathrm{TiO}_{2}-\mathrm{PE}$ films. This is possibly due to the faster bacterial inactivation kinetics induced by $\mathrm{FeOx}_{-}-\mathrm{TiO}_{2}-\mathrm{PE}$ films seen in Figure 1.

\subsection{Suggested mechanism of bacterial inactivation by $\mathrm{FeOx}_{-} \mathrm{TiO}_{2}-\mathrm{PE}$ films,}

Figure 1 showed that $\mathrm{FeOx}-\mathrm{TiO}_{2}-\mathrm{PE}$ films led to bacterial inactivation within 90 minutes. This kinetic is faster compared to the 120 min required by FeOx-PE films. Figure 7 suggests a mechanism for the electron transfer from FeOx into lower lying $\mathrm{TiO}_{2}$ trapping states. Leytner et al., [40] by time-resolved photoacoustic spectroscopy (TRPAS) identified the electron trapping sites in anatase positioned at $\sim 0.8 \mathrm{eV}$ below the anatase $\mathrm{cb}$. Gray et al., [41] used electron paramagnetic resonance (EPR) spectroscopy to report anatase trapping sites located $\sim 0.5-0.8 \mathrm{eV}$ below the anatase $\mathrm{cb}$. FeOx (mainly $\mathrm{Fe}_{2} \mathrm{O}_{3}$ ) powders have been reported to present $\mathrm{cb}$ located $0.4-0.6 \mathrm{eV}$ below anatase $[9,18,28]$. The mechanism of the bacterial inactivation mediated by $\mathrm{TiO}_{2}-\mathrm{PE}$ was outlined above 
in eqs.(1-7). The intervention of $\mathrm{FeOx}$ injecting $\mathrm{e}^{-}$into $\mathrm{TiO}_{2}$ is suggested in eqs.(3-13):

$$
\begin{aligned}
& \mathrm{FeOx}+\text { Vis light } \rightarrow \mathrm{FeOx}(\mathrm{e}-)+\mathrm{FeOx}(\mathrm{h}+) \\
& \mathrm{FeOx}(\mathrm{e}-)+\mathrm{TiO}_{2} \rightarrow \mathrm{FeOx}+\mathrm{TiO}_{2}\left(\mathrm{e}_{\text {-trapped site }}\right) \\
& \mathrm{FeOx}\left(\mathrm{e}^{-}\right)+\mathrm{O}_{2} \rightarrow \mathrm{FeOx}+\mathrm{O}_{2}^{-} \\
& \mathrm{O}_{2}^{-}{ }^{-}+\mathrm{H}^{+} \rightarrow \mathrm{HO}_{2}{ }^{\circ} \rightarrow \mathrm{ROS} \text { (reactive oxygen species) } \\
& \mathrm{TiO}_{2}\left(\mathrm{e}_{\text {-trapped site }}\right)+\mathrm{O}_{2} \rightarrow \mathrm{TiO}_{2}+\mathrm{O}_{2}^{-} \rightarrow \mathrm{ROS} \text { species } \\
& \mathrm{TiO}_{2}(\mathrm{~h}+)+\text { bacteria } \rightarrow \mathrm{CO}_{2}+\mathrm{H}_{2} \mathrm{O}+\text { inorganic/organic residues }
\end{aligned}
$$

A mechanism of reaction between $\mathrm{FeOx}-\mathrm{TiO}_{2}-\mathrm{PE}$ and bacteria under visible light is suggested hereafter in eq.(14):

Bacteria $+\left[\mathrm{FeOx}-\mathrm{TiO}_{2}-\mathrm{PE}\right]+$ Vis light $\rightarrow$ [bacteria...Fe $\left.{ }^{*} \mathrm{Ox}-\mathrm{TiO}_{2}\right] \mathrm{PE} \rightarrow$ $\left[\right.$ bacteria* $\left.\ldots . . . \mathrm{FeOx}-\mathrm{TiO}_{2}\right] \mathrm{PE} \rightarrow\left[\right.$ bacteria $\left.+\ldots \mathrm{FeOx}-\mathrm{TiO}_{2}(\mathrm{e}-)\right] \mathrm{PE}$.

3.5 Scavenging of oxidative radicals (ROS) during bacterial inactivation in aerobic media

Photocatalytic inactivation of bacteria in aerobic conditions proceeds by the highly oxidative radicals: $\mathrm{OH}^{\circ}, \mathrm{HO}_{2}{ }^{\circ} \mathrm{O}_{2}{ }^{-}$and $\mathrm{cb}\left(\mathrm{h}^{+}\right)$. Figure 8 presents the scavenging by dimethyl-sulfoxide (DMSO), superoxide dismutase (SOD) and ethylene-tetra-acetic acid di-sodium salt (EDTA-2Na) to sort out the role of the $\mathrm{OH}^{\circ}, \quad \mathrm{O}_{2}^{-}$and $\mathrm{TiO}_{2} \mathrm{vb}\left(\mathrm{h}^{+}\right) / \mathrm{FeOxvb}\left(\mathrm{h}^{+}\right)$respectively intervening in bacterial inactivation $[5,9,18,39]$. The $\mathrm{TiO}_{2} \mathrm{vb}\left(\mathrm{h}^{+}\right) / \mathrm{FeO} \mathrm{xvb}\left(\mathrm{h}^{+}\right)$valence holes seem to be the most efficient intermediate species leading to bacterial inactivation as shown in Figure 8.

The $\mathrm{OH}^{\circ}$-radical would undergo the reduction $\mathrm{OH}^{\circ} / \mathrm{OH}^{-}$when oxidizing bacteria (organic matter) with a potential of $1.9 \mathrm{eV}$ vs NHE. The $\mathrm{HO}_{2}{ }^{\circ}$ radical at the $\mathrm{pH}$ of the bacterial inactivation shown in figure 6 (between 6 and 7 ) is present as $\mathrm{O}_{2}{ }^{-\circ}$, according to the reaction: $\mathrm{HO}_{2}^{\circ} \leftrightarrow \mathrm{H}^{+}+\mathrm{O}_{2}{ }^{\circ}$ (pka of 4.8). This photo-generated $\mathrm{O}_{2}^{-\circ}$ have a potential of $0.75 \mathrm{eV}$ vs NHE. Finally, the $\mathrm{TiO}_{2}(\mathrm{vbh}+)$, being the most 
oxidizing species in the system, have a potential of $2.7 \mathrm{eV}$ at $\mathrm{pH}$. They would be the third species oxidizing the bacteria as shown in figure 8.

\section{Conclusions}

The effect of colloidal $\mathrm{FeOx}-\mathrm{TiO}_{2}-\mathrm{PE}$ films accelerating the bacterial inactivation was compared to $\mathrm{TiO}_{2}-\mathrm{PE}$ and $\mathrm{FeOx}-\mathrm{PE}$ films. The $\mathrm{FeOx}-\mathrm{TiO}_{2}-\mathrm{PE}$ films release ppm amounts Fe during the repetitive recycling, but the film spectral absorption was not affected by the Fe-release. The induction of hydrophilicity in the FeOx$\mathrm{TiO}_{2}-\mathrm{PE}$ film during of the bacterial inactivation period favors the contact between $E$. coli and the film since $E$. coli presents a predominantly hydrophilic cell-wall envelope. Redox catalysis involving $\mathrm{Fe}$ - and Ti-species takes place during bacterial inactivation as reported by XPS experiments. The surface potential decreased during the period of bacterial inactivation due to the photo-induced damage on the cell-wall functional groups and mechanical integrity.

\section{Acknowledgments}

We thank the EPFL and the Swiss National Science Foundation (SNF) Project (200021-143283/1) for financial support. We also thank the COST Action 1106 for interactive discussions during the course of this study.

\section{References}

[1] H. A. Foster, I. B. Ditta. S. Varghese, A. Steele, Photo catalytic disinfection using titanium dioxide: Spectrum and mechanism of antimicrobial activity, Appl. Microb and Biotechnol, 90 (20111) 1847-1868.

[2] J-A Byrne, P.S.M. Dunlop, J. H. Hamilton, P. Fernadez-lbanes, I. Polo-Lopez, P. Kumar Sharma, A. S. Vennard, A Review of Heterogeneous Photocatalysis for Water Disinfection, Molecules, 20 (2015) 5574-5615.

[3] A. Kubacka, M. Suarez-Diez, D. Rojo, R. Bargiela, S. Ciordia, I. Zapico, J. Albar, C. Barbas, V. Martins dos Santos, M. Fernandez Garcia, M. Ferrer, Understanding the antimicrobial mechanism of $\mathrm{TiO}_{2}$-based nanocomposite films in a pathogenic bacterium, Nature Scientific Reports, 4 (2014) 4134-4139.

[4] K. Page, W. Wilson, I. P. Parkin, Antimicrobial surfaces and their potential in reducing the role of the inanimate environment in the incidence of hospitalacquired infections, J. Mater. Chem. 19 (2009) 3819-3831.

[5] M. Pelaez, N. Nolan, S.C. Pillai, M. Seery, Po Falaras, A. Kontos, M.S.P. Dunlop, J. Hamilton, J-A. Byrne, K. O'Shea, M. Entezari, D. Dionysiou. A review on the 
visible light active titanium dioxide photocatalsts for environmental applications Appl. Cat. B, 125 (2012) 331-345.

[6] R. Fagan, D. McCormack, D. Dionysiou, S.C. Pillai, A review of solar and visible light active $\mathrm{TiO}_{2}$ photocatalysis for treating bacteria, cyanotoxins and contaminants of emerging concern, Mat. Science in Semiconductor Processing, 42 (2016) 2-14.

[7] J. Podorska-Carroll, E. Panaitescu, B. Quilty, L. Wang, L. Menon, S. C. Pillai, Antimicrobial properties of highly efficient photocatalytic $\mathrm{TiO}_{2}$ nanotubes, Appl. Cat. B, 176-177 (2015) 70-75.

[8] S. Rtimi, C. Pulgarin, A. Houas, R. Sanjines, J-C. Lavanchy, J. Kiwi, Coupling of narrow and wide band-gap semiconductors on uniform films in bacterial disinfection under low intensity visible light: Implications of the interfacial charge transfer (IFTC), Hazardous Mat, 260 (2013) 860-868

[9] J. Schneider, M. Matsuoka, M. Takeuchi, J. Zhang, Y. Horiuchi, M. Anpo, D. Bahnemann, Understanding $\mathrm{TiO}_{2}$ Photocatalysis: Mechanisms and Materials, Chem. Rev. 118 (2014) 9919-9986

[10] M. Mishra, D. Chun, Alfa- $\mathrm{Fe}_{2} \mathrm{O}_{3}$ as a photocatalytic material: A review, Applied Cat A, 498 (2015) 126-141.

[11] J. Kiwi, M. Graetzel, Light Induced Hydrogen Formation and Photo-uptake of Oxygen in Colloidal Suspensions of Alfa $\mathrm{Fe}_{2} \mathrm{O}_{3}$, J. Chem, Soc. Faraday Trans. 1, 83 (1987) 1101-1108.

[12] W. Zhou, H. Fu, K. Pan, C. Tian, Y. Qu, Mesoporous $\mathrm{TiO}_{2} / \alpha-\mathrm{Fe}_{2} \mathrm{O}_{3}$ : Bifunctional Composites for Effective Elimination of Arsenite Contamination through Simultaneous Photocatalytic Oxidation and Adsorption, J. Phys. Chem. C, 112 (2008) 19584-19592.

[13] Y. Cong, Z. Li, Y. Zhang, Q. Wang, Q. Xu, Synthesis of $-\mathrm{Fe}_{2} \mathrm{O}_{3} / \mathrm{TiO}_{2}$ nanotube arrays for photoelectro-Fenton degradation of phenol Chem. Eng J. 191 (2012) 356-363.

[14] B. Palanisamy, C. Babu, B. Sundarevel, S. Anandan, V. Murugesan, Sol-gel synthesys of mesoporous mixed $\mathrm{Fe}_{2} \mathrm{O}_{3} / \mathrm{TiO}_{2}$ photocatalyst: Application for degradation of 4-chlorophenol, J. Hazardous Mat. 252 (2013) 233-242

[15] Q. Zhang, G. Rao, J. Rogers, C. Zhao, L. Liu, Y. Li, Novel anti-fouling $\mathrm{Fe}_{2} \mathrm{O}_{3} / \mathrm{TiO}_{2}$ nanowire membranes for humic acid removal from water, Chem. Eng. J. 271 (2015) 180-187.

[16] Novel FeOx-polyethylene (PE) Transparent Films: synthesis and mechanism of surface regeneration, S. Rtimi, C. Pulgarin, R. Sanjines, J. Kiwi, RSC Adv. 5 (2015) 80203-80211.

[17] Innovative photocatalyst $\left(\mathrm{FeOx}-\mathrm{TiO}_{2}\right)$ : transients induced by Femtosecond laser leading to bacterial inactivation under visible light S. Rtimi, R. Sanjines, J. Kiwi, C. Pulgarin, M. Bensimon, I. Kmehl, V. Nadtochenko, RSC Advances, 5 (2015) 101751-101759. 
[18] A. Fujishima, X. Zhang, D, Tryck, $\mathrm{TiO}_{2}$ photocatalysis and related surface phenomena, Surf. Sci. Repts. 63 (2008) 515-546.

[19] M. Mohaptra and S. Anand, Synthesis and applications of nanostructured iron oxides/hydroxides -a review, Int. J. Sci. Tech., 2 (2010) 127-146.

[20] M. Dhananjeyan, E. Mielczarski, K. Thampi, Ph. Buffat, M. Bensimon, A. Kulik, J. Mielczarski and J. Kiwi, Photodynamics and Surface Characterization of Immobilized $\mathrm{TiO}_{2}$ and $\mathrm{Fe}_{2} \mathrm{O}_{3}$ Photo- catalysts on Modified Polyethylene Films. J. Phys. Chem. B, 105 (2000) 12046-12055.

[21] J. Fernandez, J. Bandara, A. Lopez, Ph. Buffat and J. Kiwi Photo-assisted Fenton Degradation of Non-biodegradable Azo-dye (Orange II) in Fe-free Solutions Mediated by Cation Transfer Membranes, Langmuir, 15 (1999) 18592

[22] J.S. Dancer, The role of environmental cleaning in the control of hospitalacquired infection. The Journal of hospital infection 73 (2009) 378-385.

[23] I. Kramer, I. Schwebke, G. Kampf, How long do nosocomial pathogens persist on inanimate surfaces? A systematic review, BMC Infectious Dis, 6 (2006) 137-146.

[24] L. L. Stookey, Ferrozine, a new spectrophotometric reagent for iron, Anal. Chem, 42 (1970) 779-781.

[25] C. Wagner, W. Riggs, L. Davis, G. Mullenberg, (Eds) Handbook of X-ray Photoelectron spectroscopy, Perkin-Elmer Corporation Physical Electronics Division, Minnesota, USA, 1979.

[26] J. Nogier, M. Delamar, P. Ruiz, M. Gratzel, R. Thampi, J. Kiwi, X-ray Photoelectron Spectroscopy of $\mathrm{V}_{2} \mathrm{O}_{5} / \mathrm{TiO}_{2}$ Catalysts Catal. Today, 20 (1994) 109119.

[27] P. Wardman, Reduction Potentials of one Electron Couples Involving Free Radicals in Aqueous Solutions, J. Phys. Chem. Ref. Data 18 (1989) 1637-1755.

[28] International Organization for Standardization: Water quality determination of iron, Geneva, 1988 (ISO 6332:1988), Guidelines for drinking-water quality, 2nd ed. Vol. 2: Health criteria and supporting information, World Health Organization, Geneva, 1996.

[29] K. Hardee, A. Bard, Photochemical Behavior of Several Polycrystalline Oxides Electrodes in Aqueous Solutions, J. Electrochemistry. Soc. 124 (1977) 215-224.

[30] N. Sakai, A. Fujishima, T. Watanabe, K. Hashimoto, Enhancementof the photoinduced hydrophilic conversion rate of $\mathrm{TiO}_{2}$ film electrode surfacesby anodic polarization, J. Phys. Chem ChemB,105 (2001) 3023-3026.

[31] K. Hashimoto, Hirie, A. Fujishima, $\mathrm{TiO}_{2}$ photocatalysis: an overview and furure prospects AAPPS Bull. 17 (2005) 12-28. 
[32] C. Gunawan, W. Teoh, P. Marquis, J. Lifla, R. Amal, Reversible antimicrobial photoswitching nanosilver, Small, 5 (2009) 341-344.

[33] M. van Loosdrecht, J. Lyklema, W. Norde, G. Schraa, A. Zehnder, The role of Bacterial cell-wall hydrophobicity in adhesiaon,Appl. Environ. Microb., 53 (1987) 1893-1001

[34] A. D. Shirley, Corrections for electrostatic charged species in XPS-spectroscopy, Phys. Rev. B5 (1987) 4709-4716.

[35] V. Nadtochenko and J. Kiwi, Photolysis of $\mathrm{FeOH}^{2+}$ and $\mathrm{FeCl}^{2+}$ in Aqueous Solution: Photo-Dissociation Kinetics and Quantum Yields, Inorg. Chem. 1998, (37) 5233.

[36] A. Kraeutler, A. Bard, J. Am. Chem. Soc. 1100 (1978) 239-2244.

[37] Z. Lu, L. Zhou, Z. Zhang, W. Shi, Z. Xie, H. Xie, D. Pang, P. Shen, Cell Damage Induced by Photocatalysis in $\mathrm{TiO}_{2}$ Thin Films, Langmuir, 19 (2003) 8765-8768.

[38] J. G Fitz, T. E, Trouuillot, B. F. Scharschmidt, Effect of pH on membrane potential and $\mathrm{K}^{+}$conductance in cultured rat hepatocytes, Gastro and Liver Phys. 257 (1989) G961-G968.

[39] J. Kiwi and V. Nadtochenko, New evidence for $\mathrm{TiO}_{2}$ photocatalysis during bilayer lipid peroxidation, J. Phys. Chem. B., 109 (1994) 2004, 17675-17684.

[40] S. Leytner, J.T. Hupp, Evaluation of the energetics of electron trap states at the nanocrystalline titanium dioxide/aqueous solution interface via timeresolved photo-acoustic spectroscopy, Chem. Phys. Lett. 330, 2000) 231237.

[41] D. C. Hurum, A. G. Agrios, K. A. Gray, T. Rajh, M. C. Thurnauer. J.Phys. Chem. B, Explaining the Enhanced Photocatalytic Activity of Degussa P25 Mixed-Phase $\mathrm{TiO}_{2}$ Using EPR, 107 (2003) 4545-45490. 


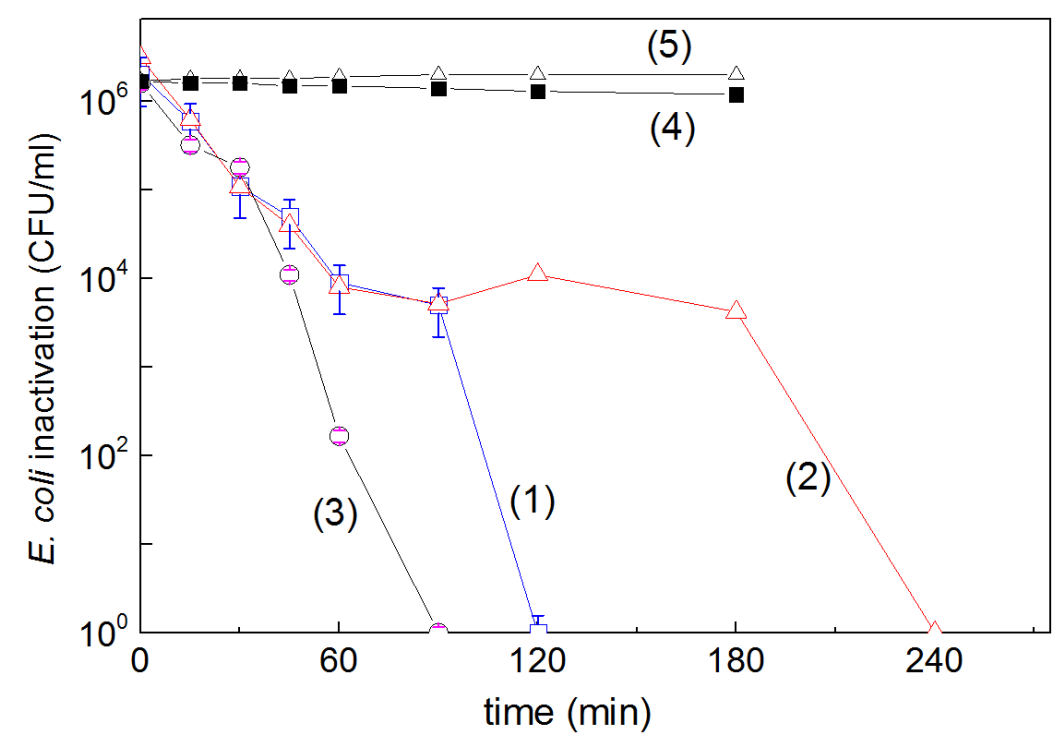

Figure 1. E. coli inactivation (CFU/ml) on PE-films coated with (1) FeOx and (2) $\mathrm{TiO}_{2}$ and (3) $\mathrm{FeOx}-\mathrm{TiO}_{2}$ under low intensity solar simulated light $\left(50 \mathrm{~mW} / \mathrm{cm}^{2}\right)$.
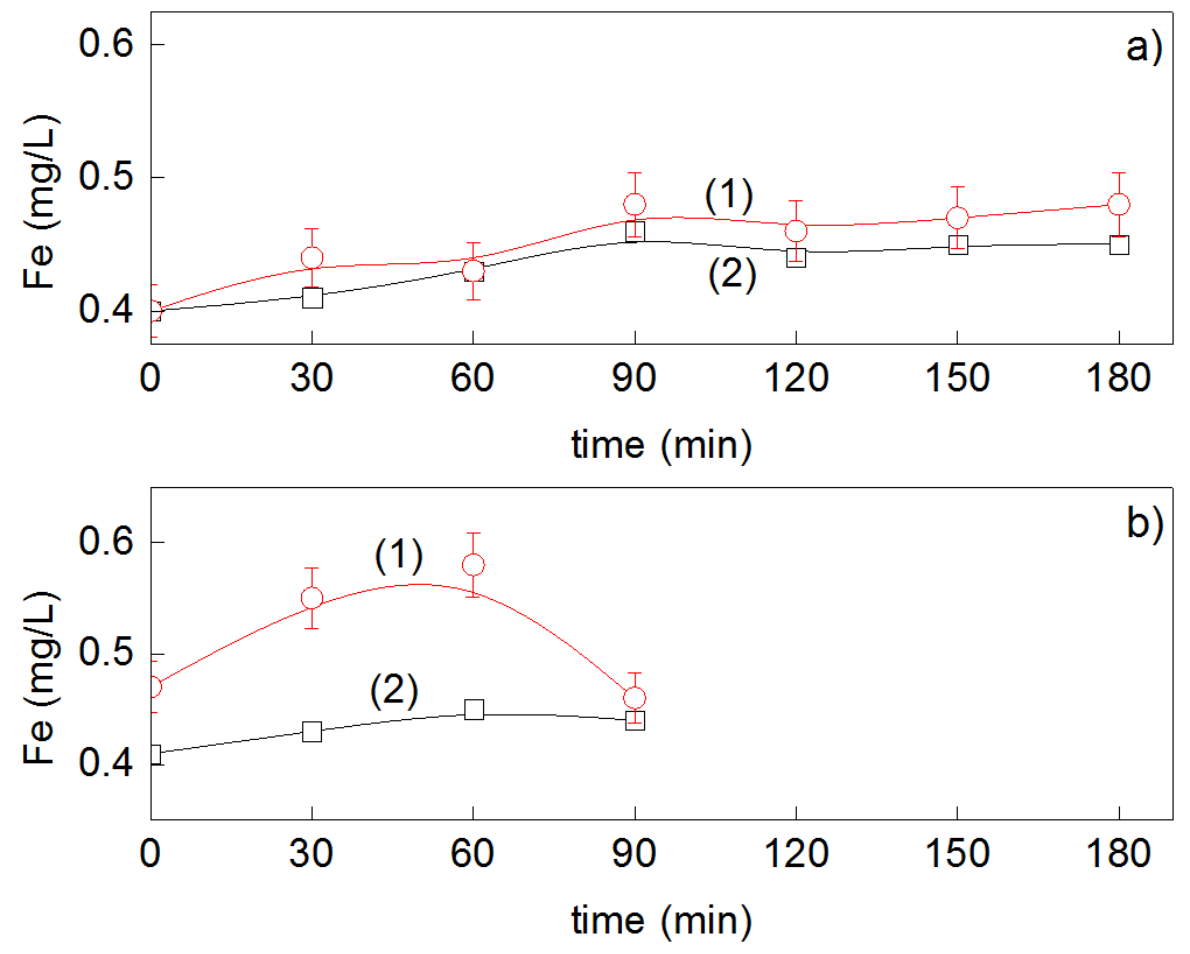

Figure 2a. Trace 1) presents the $\mathrm{Fe}(\mathrm{mg} / \mathrm{L})$ leached out from a solution $\mathrm{FeOx}-\mathrm{PE}$ under sunlight with a Fe loading of $0.261 \mathrm{wt} \% / \mathrm{wt} \mathrm{PE}$ in the presence of $10^{6}$ $\mathrm{CFU} / \mathrm{ml}$. Trace 2 presents the Fe-leaching from similar films but in the absence of E. coli.

Figure 2 b. Trace 1) presents the $\mathrm{Fe}(\mathrm{mg} / \mathrm{L})$ leached out from a solution $\mathrm{FeOx}$ $\mathrm{TiO}_{2}-\mathrm{PE}$ under sunlight with a $\mathrm{Fe}$ loading of $0.788 \mathrm{wt} \% / \mathrm{wt} \mathrm{PE}$ in the presence of $10^{6} \mathrm{CFU} / \mathrm{ml}$. Trace 2 presents the Fe-leaching from similar films but in the absence of $E$. coli. 

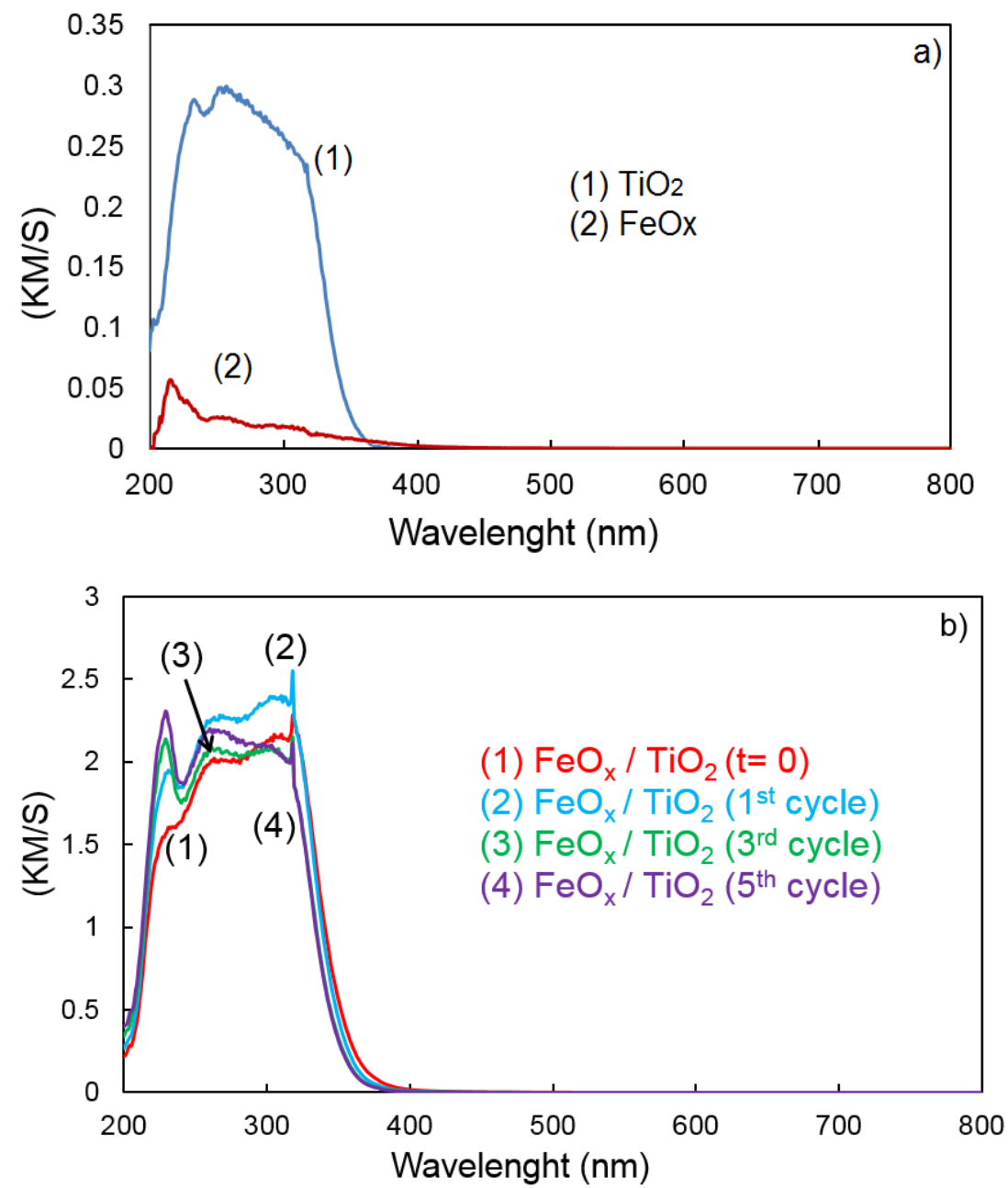

Figure 3a. Diffuse reflectance spectroscopy (DRS) of $\mathrm{TiO}_{2}$ and $\mathrm{FeOx}$ coated PEfilms, Figure 3b. Diffuse reflectance spectroscopy (DRS) of $\mathrm{FeOx}-\mathrm{TiO}_{2}$ coated PE up to the fifth recycling after bacterial inactivation. 


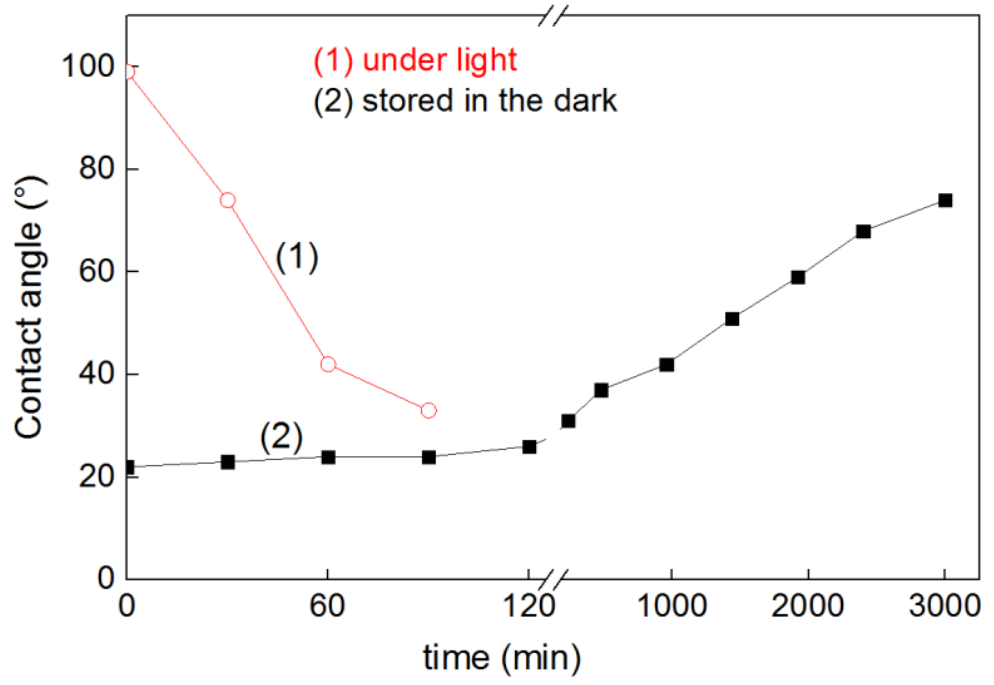

Figure 4. Trace 1: Contact angle (CA) kinetics during the hydrophobichydrophilic kinetics of the $\mathrm{FeOx}-\mathrm{TiO}_{2}-\mathrm{PE}$ film under low intensity solar light $\left(50 \mathrm{~mW} / \mathrm{cm}^{2}\right)$, Trace 2: reverse hydrophilic-hydrophobic back kinetics after bacterial inactivation (samples kept in the dark). 

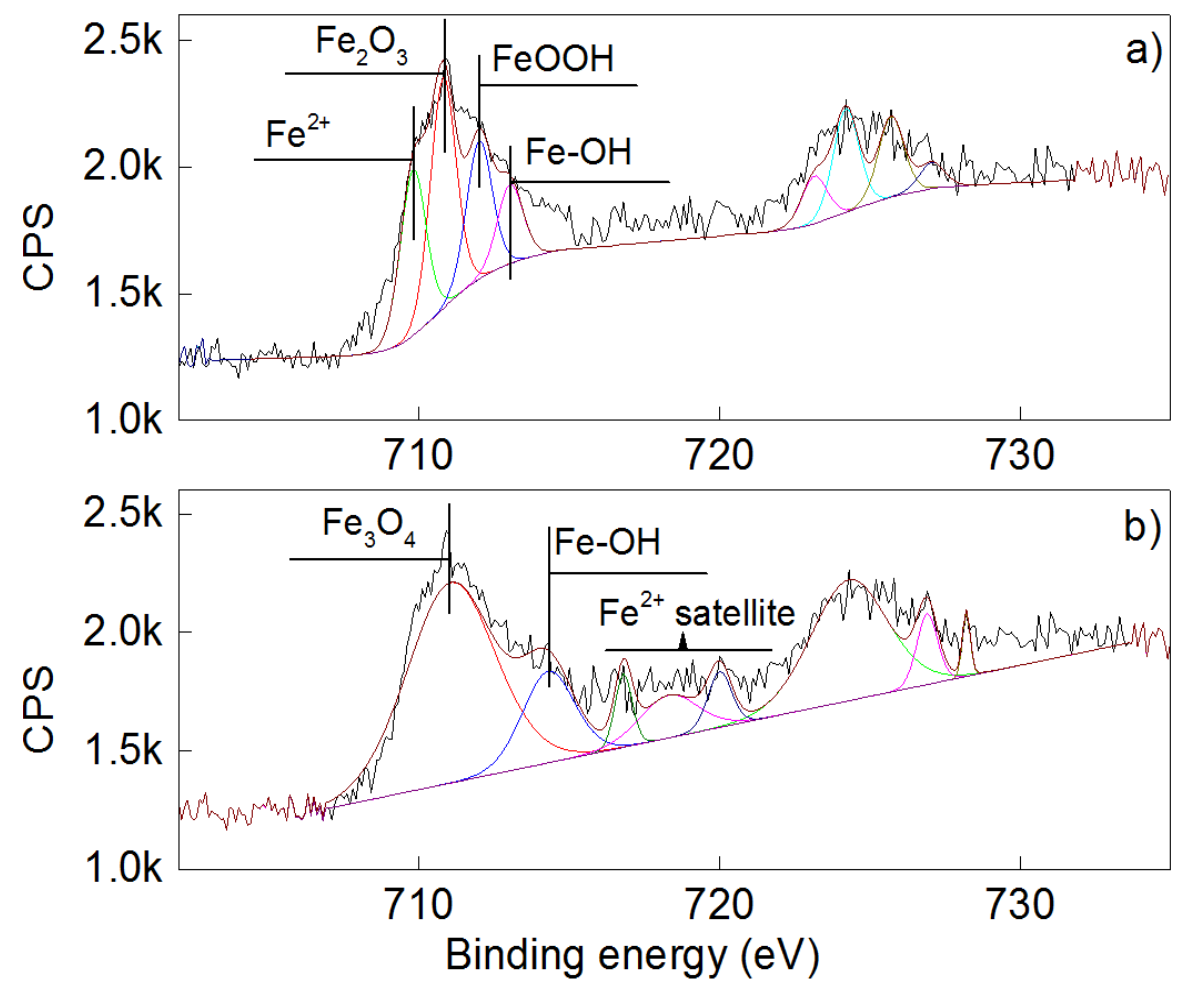

Figure 5a. XPS deconvolution of the Fe2p doublet on $\mathrm{FeOx}-\mathrm{TiO}_{2}-\mathrm{PE}$ films: (a) before and (b) after bacterial inactivation under solar simulated light (50 $\mathrm{mW} / \mathrm{cm}^{2}$ ).
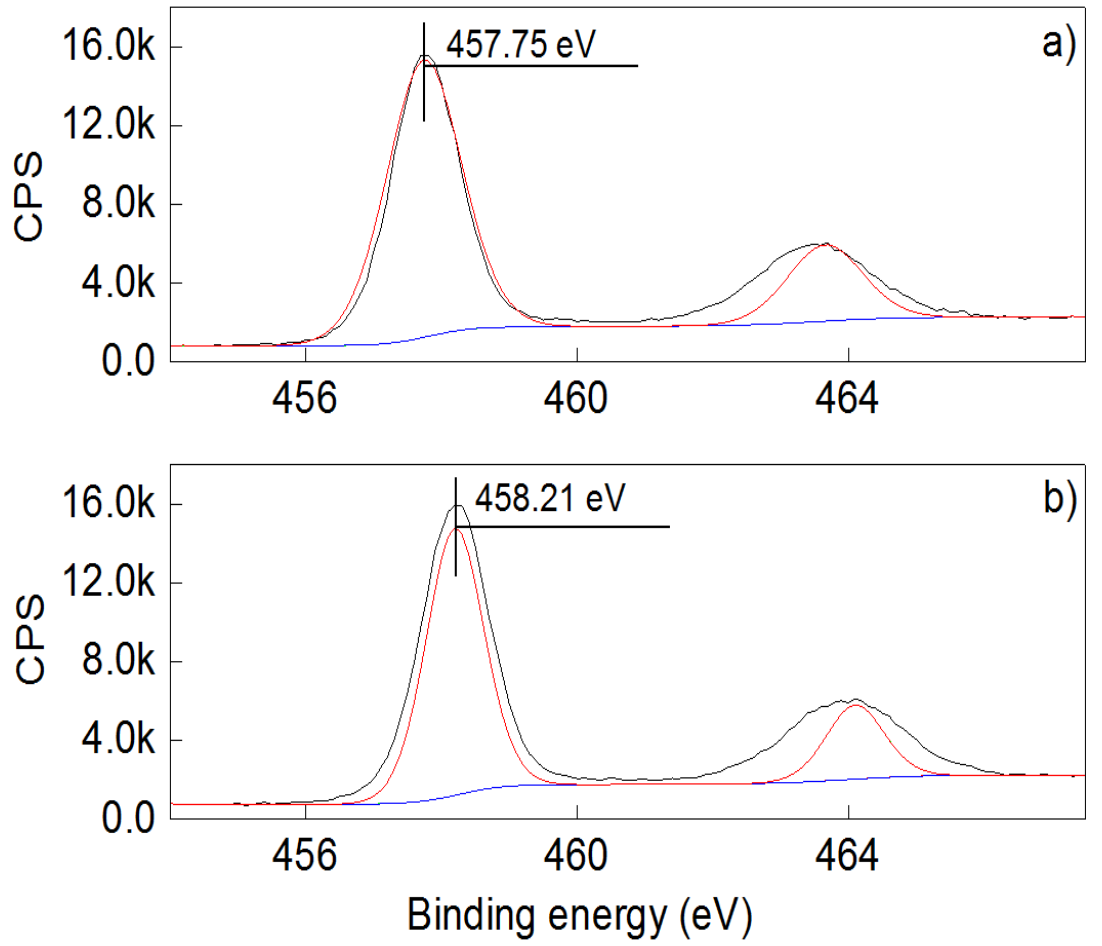

Figure 5b. XPS deconvolution of Ti2p doublet on $\mathrm{FeOx}-\mathrm{TiO}_{2}-\mathrm{PE}$ : (a) before and (b) after bacterial inactivation under solar simulated light $\left(50 \mathrm{~mW} / \mathrm{cm}^{2}\right)$. 


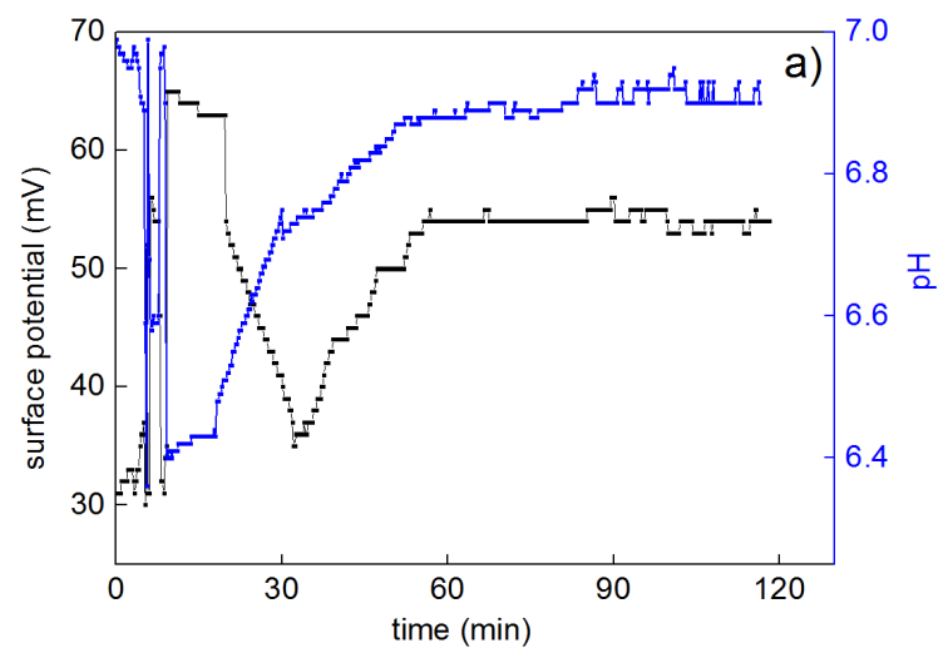

Figure 6a. Surface $\mathrm{pH}$ and potential changes on FeOx-PE films during bacterial inactivation under solar simulated light $\left(50 \mathrm{~mW} / \mathrm{cm}^{2}\right)$.

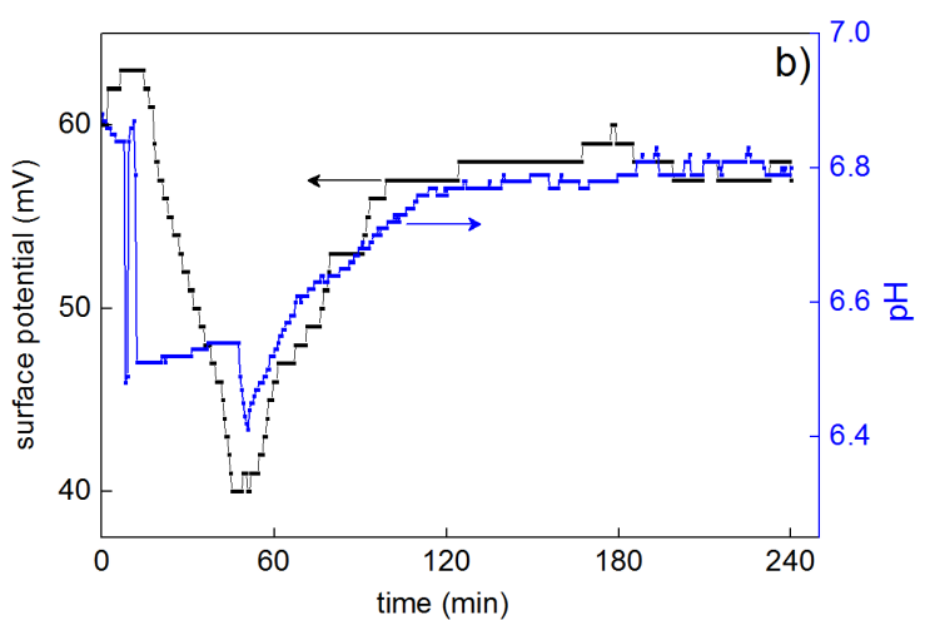

Figure 6b. Surface $\mathrm{pH}$ and potential changes on $\mathrm{TiO}_{2}-\mathrm{PE}$ films during bacterial inactivation under solar simulated light $\left(50 \mathrm{~mW} / \mathrm{cm}^{2}\right)$.

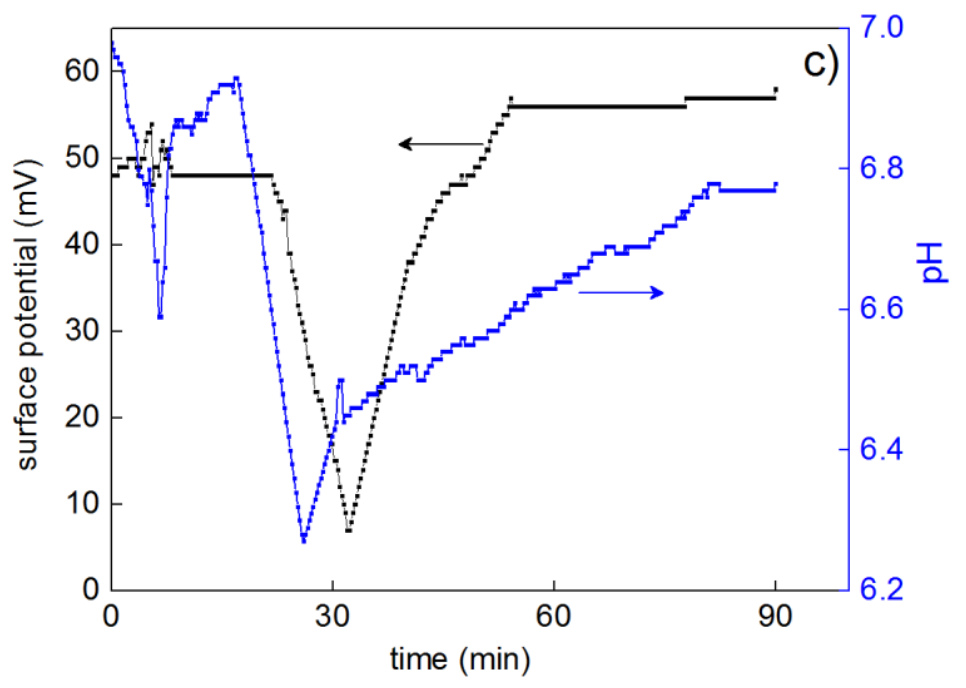

Figure 6c. Surface $\mathrm{pH}$ and potential changes on $\mathrm{FeOx}-\mathrm{TiO}_{2}-\mathrm{PE}$ films during bacterial inactivation under solar simulated light $\left(50 \mathrm{~mW} / \mathrm{cm}^{2}\right)$. 


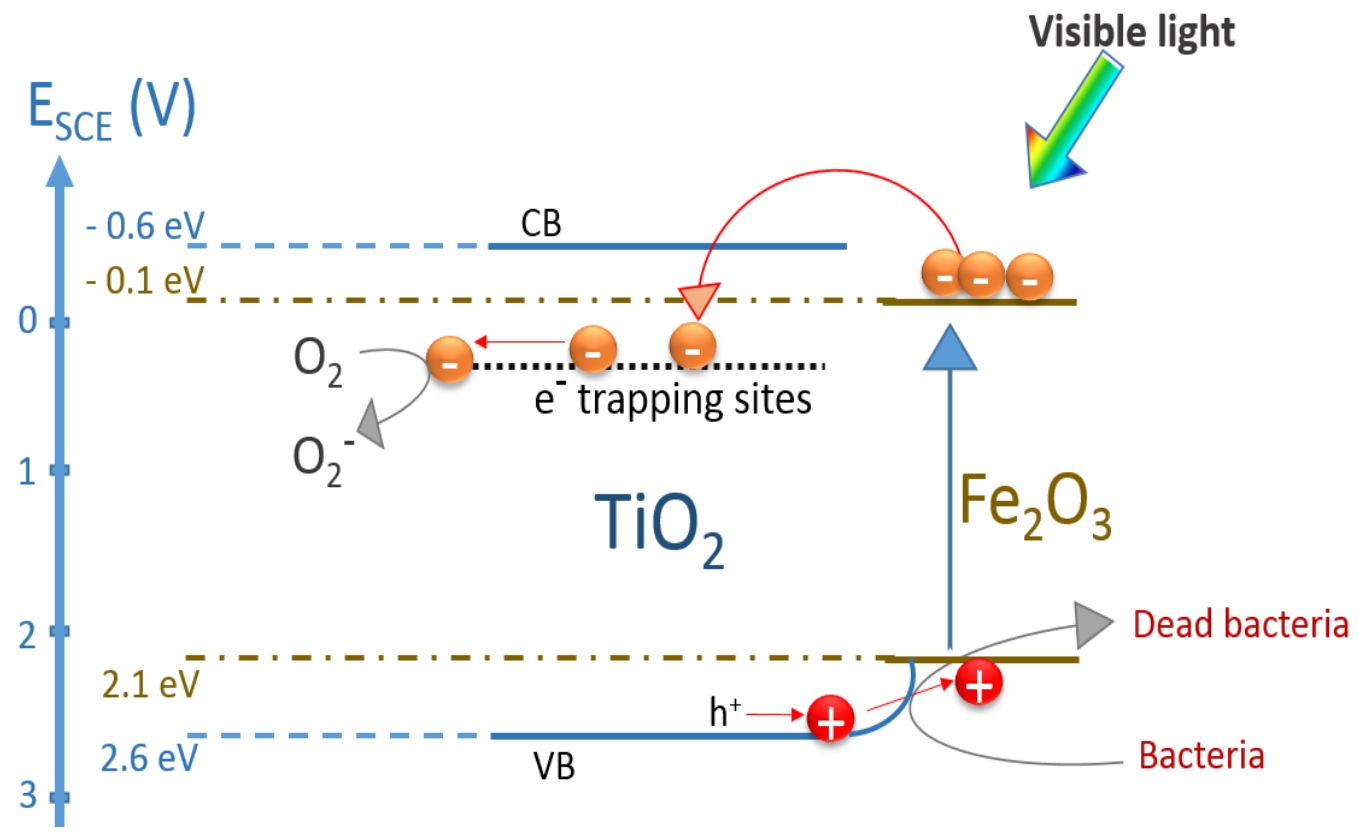

Figure 7. Interfacial charge transfer (IFCT) electron transfer between FeOx and low-lying $\mathrm{TiO}_{2}$ trapped states. 


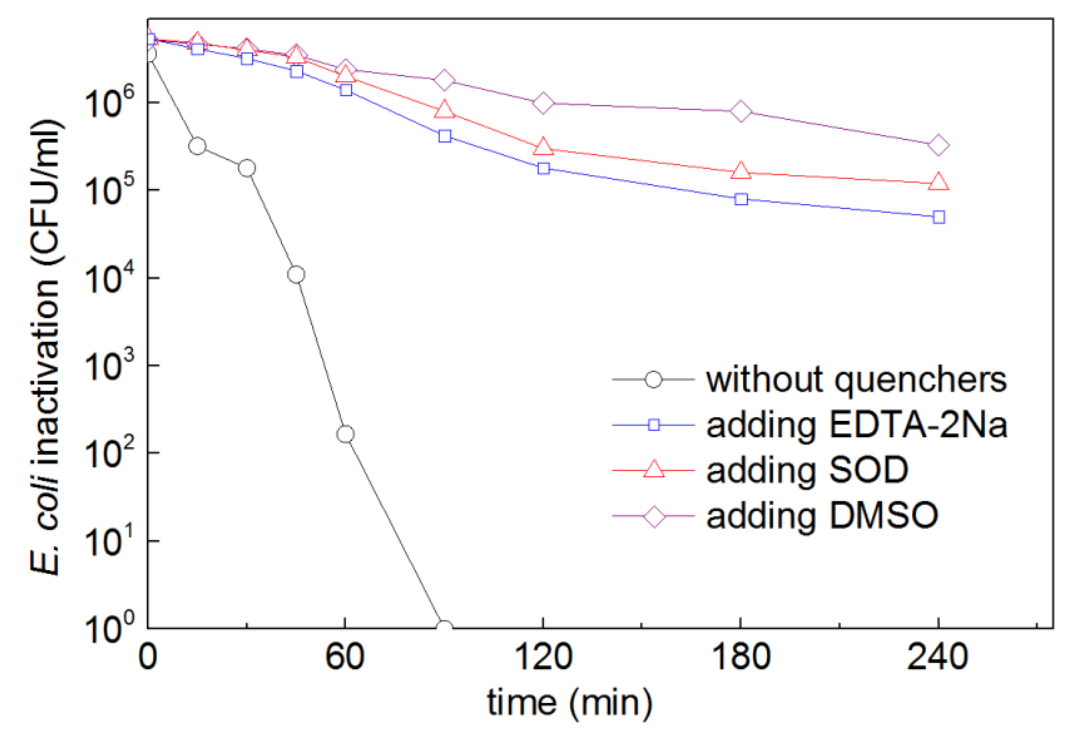

Figure 8. E. coli inactivation on $\mathrm{FeOx}-\mathrm{TiO}_{2}-\mathrm{PE}$ film by itself and upon addition of ROS quenchers under solar simulated light $\left(50 \mathrm{~mW} / \mathrm{cm}^{2}\right)$. 
Table 1. Loading of polyethylene (PE) by $\mathrm{FeOx}, \mathrm{TiO}_{2}$ and $\mathrm{FeOx}-\mathrm{TiO}_{2}$ determined by X-ray fluorescence (XRF)

\begin{tabular}{|l|c|c|}
\hline & Fe wt\%/wt PE & Ti wt\%/wt PE \\
\hline FeOx $(25 \mathrm{mg} / \mathrm{L})$ & 0.076 & -- \\
\hline $\mathrm{FeO}(100 \mathrm{mg} / \mathrm{L})$ & 0.261 & -- \\
\hline $\mathrm{FeOx}(150 \mathrm{mg} / \mathrm{L})$ & 0.240 & -- \\
\hline $\mathrm{TiO}_{2}(200 \mathrm{mg} / \mathrm{L})$ & -- & 0.788 \\
\hline $\mathrm{TiO}_{2}(250 \mathrm{mg} / \mathrm{L})$ & -- & 0.624 \\
\hline $\mathrm{FeO}(100 \mathrm{mg} / \mathrm{L}) / \mathrm{TiO}_{2}(250 \mathrm{mg} / \mathrm{L})$ & 0.075 & 0.655 \\
\hline $\mathrm{FeOx}(25 \mathrm{mg} / \mathrm{L}) / \mathrm{TiO}_{2}(200 \mathrm{mg} / \mathrm{L})$ & 0.063 & 0.702 \\
\hline
\end{tabular}




\section{Graphical Abstract:}

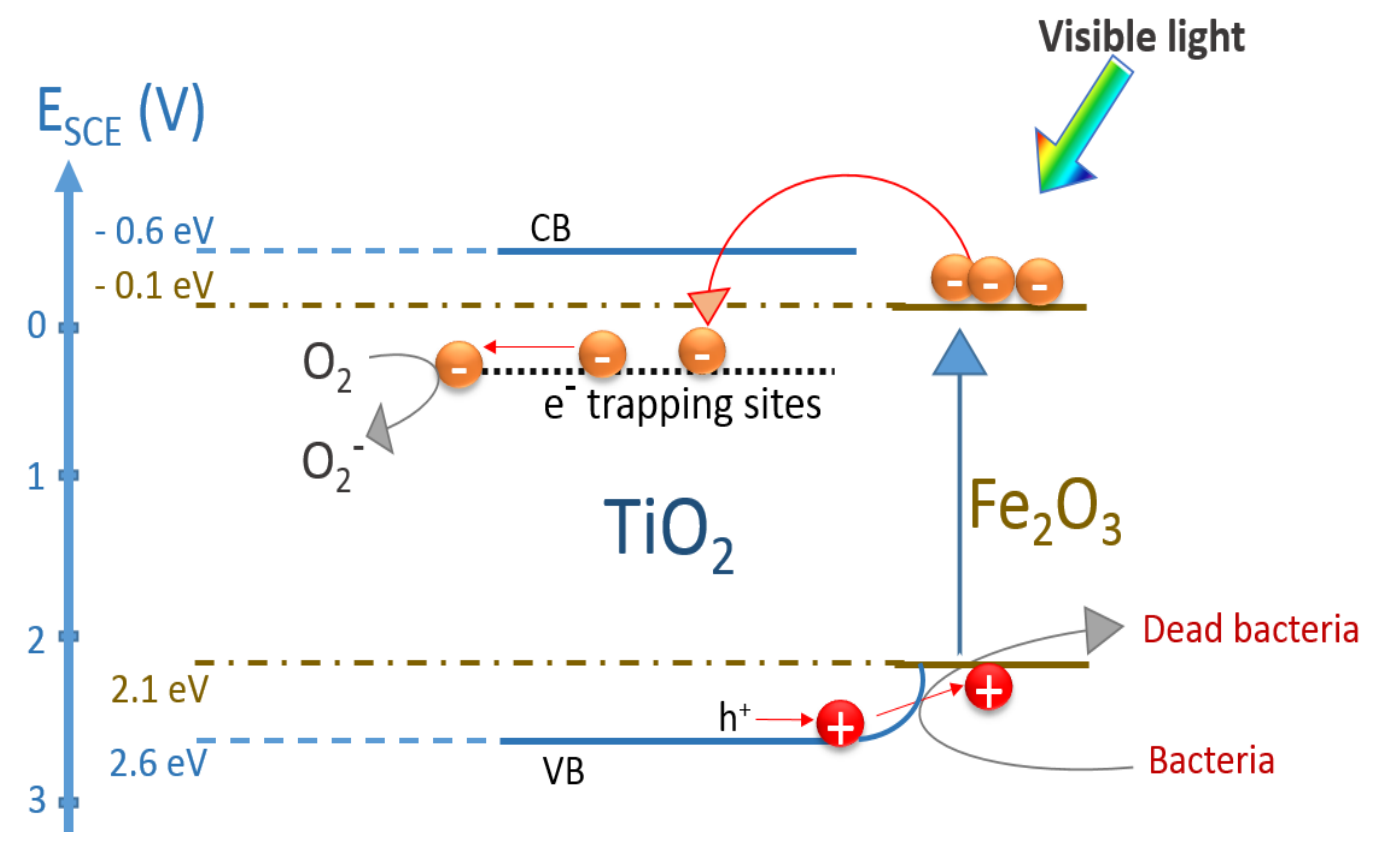

